survey of the growth of our clinical knowledge of brain tumours. Advance has come principally through the use of special methods of clinical investigation, from the introduction of the ophthalmoscope up to our present-day use of such methods as ventriculography and encephalography. The second session of the section discussed the psychoses of adolescence, and the malarial treatment of neurosyphilis, the latter subject being illustrated by exhibits in the museum.

The Section of Ophthalmology, under the presidency of Dr. A. J. Ballantyne, discussed glaucoma, false binocular projection and abnormal retinal correspondence, idiopathic cyclitis and several minor subjects. On all the topics, the discussions were of considerable interest, and contained original work or ideas.

The Section of Orthopædics, presided over by Prof. Hey Groves, discussed fractures of the neck of the femur, osteoarthritis of the hip and knee, fractures of the spine, and the role of physiotherapy in orthopædic practice.

The Section of Oto-Rhino-Laryngology, under Mr. F. Muecke, considered maxillary and nasal sinusitis, chronic suppurative otitis media, sphenoidal sinusitis in relation to the pituitary gland and actinotherapy in laryngeal tuberculosis.

The Section of Pathology and Bacteriology was presided over by Prof. A. M. Drennan. At its first session various aspects of pathological calcification and bone disease were discussed, the principal paper being one on the pathology of osseous tissue by Prof. Drennan. A paper on leukæmic infiltrations was read by Prof. J. B. Cleland; and one on the neural components of teratomata, by Dr. R. A. Willis, this being amplified by photographs and maps exhibited in the museum. The second meeting of the section was largely devoted to bacteriology. A discussion on anærobes in disease was opened by Prof. H. A. Woodruff with an informative paper on anærobic infections in animals; and Dr. F. M. Burnet introduced a discussion on virus diseases, stressing the frequent occurrence of mild, but immunising, attacks of these and other infections. A new method of hæmoglobin estimation, based on the formation of globin picrate, was described by Dr. Bolliger.

The Section of Pharmacology, Therapeutics and Anæsthesia, under the presidency of Sir William
Willcox, discussed hypnotic drugs, urinary antiseptics, premedication and basal narcosis, gas anæsthesia, and spinal anæsthesia; and Prof. W. A. Osborne contributed a paper on a vaso-constrictor principle in the frog's skin.

The Section of Public Medicine, under Sir Henry Gauvain as president, dealt with tuberculosis, industrial and tropical medicine, and racial problems. At its first meeting the subject of pleural effusion in artificial pneumothorax was introduced by an in. formative paper by Dr. D. B. Rosenthal ; and $\mathrm{Mr}$. M. P. Susman opened a discussion on tuberculous empyæma. At the second meeting of the section, which was combined with the Section of Medical Sociology, the principal subject was racial pressure problems in Australia and its neighbourhood, opened by Sir R. W. Cilento.

The Section of Medical Sociology, with Dr. E. Kaye le Fleming as president, discussed the Australian medical aerial services, the social aims of mental hygiene, and along with the Section of Public Medicine, racial pressure problems opened by Sir Raphael Cilento. Sir James Barrett spoke of the difficulties of agricultural and pastoral activity in the Northern Territory, pointing out that on parts of the south coast of Java, which has a population of forty million people, areas resembling northern Australia are reported to be practically empty, and that for successful agriculture a rainfall of at least ten inches in the dry season is essential. Sir James Barrett then quoted an article by Mr. Wynne Williams, from the last number of the Economic Record, to the effect that apart from Queensland, Northern Australia is economically incapable of carrying a large population of any race. The difficulty is not physiological but entirely economic.

The Section of Dermatology was presided over by Dr. S. Watson Smith. The principal subject for discussion was the incidence of skin diseases in Australia, opened by Dr. Herman Lawrence. A main point brought out was the exceptionally high incidence in Australia of keratosis, rodent ulcer and epithelioma-called by Dr. Lawrence the "epithelial triad" and attributed by him largely to sunlight. An account of staphylococcal skin infections by Dr. Ivan Connor indicated the value of treatment by toxoids. Dr. J. C. Belisario contributed a paper on fungus infections.

\title{
Lumière and the Invention of Cinematography
}

\begin{abstract}
A BRILLIANT gathering took place on the evening of November 6 at the Sorbonne, in honour of M. Louis Lumière, father of the cinema and of many other inventions in the field of photography.

The great hall of the University of Paris was resplendent with high officials, including the French President, M. Lebrun, the Diplomatic Corps, distinguished academicians and representatives of numerous scientific and industrial organisations.

M. Mario Roustan, Minister of Education, presided, and speakers vied with each other in paying tribute to the qualities which have enabled M. Lumière to devote half a century of an active and fruitful life to promote applied science.
\end{abstract}

M. Armbruster, president of the Renaissance Française, who took the initiative in organising the celebrations, supplied a historical outline. He mentioned how Lumière, son of a photographer, of Besançon, developed with his brother a successful manufacturing photographic plant at Lyons, which became known throughout the world. He recalled the first public presentation, on December 28, 1895, of moving pictures in the basement of a Paris café, at $14 \mathrm{bd}$. des Capucines, amidst much scepticism and sarcasm - which, however, did not prevent the rapid success and growth of the enterprise.

M. Ch. Fabry, the distinguished physicist, spoke of the numerous applications of Lumière's work. M. Ch. Delac quoted figures to show the great 
economic importance of the cinema industry. M. Georges Lecomte, the well-known writer, enlarged upon the aesthetic value of the cinematographic art.

Sir Robert Mond, dean of the distinguished foreign delegates present, outlined the historical development of the photography of movement, and expressed the high regard in which Louis Lumière is held throughout the world.

Historically, for the beginning of cinematography, one may go back to the animated drawings devised by the Belgian physicist Antoine Plateau in 1830 , which were used in the phenakitiscope. Improved by Clerk Maxwell in 1869 and enlarged by the American, Horner, the apparatus became known as the zoetrope. Molteni, in 1850, had his choreutoscope, consisting of a glass disc on which six different positions of a moving object were drawn, so that on turning the disc the appearance of movement was produced. In 1893 Edison devised his kinetoscope, consisting of an endless film about 20 metres long, moving at such a rate that 45 images were presented per second. It had the drawback of being visible to only one person at a time.

On the photographic side, we find the American Muybridge in 1872 utilising a series of thirty cameras to photograph a galloping horse. The astronomer Janssen devised a photographic revolver in which a circular photographic plate turns round, so that 48 pictures can be taken in 62 seconds; the physiologist Jules Marey developed his chronophotograph and M. Demeny his phonoscope.

All these separate inventions and improvements do not, however, detract from the great merit of Louis Lumière, that of having devised an apparatus which will both photograph an object in motion and reproduce it afterwards upon a screen so as to give the impression of movement, in the form in which we see it to-day.

The invention of the moving picture apparatus, though the most spectacular of Lumière's inventions, forms but part of his numerous activities. In 1899 he made an apparatus for taking 'rotary' photographs, so as to be able to make a complete tour of the horizon. In 1901 he devised a 'photoramic' method of projection, and in 1907, after numerous trials, he perfected the Lumière method of colour photography still used throughout the world.

During the War, Lumière had to divert his inventive genius in other directions. He devised a method of heating the cockpit of aeroplanes, and he improved artificial limbs for mutilated soldiers. To-day, at the age of seventy-one years, we find him still active in research and invention. Recently he gave before the Academy of Sciences an exhibition of stereoscopic cinematography. At his villa at Neuilly-sur-Seine, M. Lumière has installed several laboratories that enable him to carry out his in. vestigations in cinematography and related matters.

No account of Louis Lumière would be complete without mention of his brother Auguste, by two years his senior, who has been a constant collaborator, though specialising in the fields of chemistry and biology. The original patent for a cinema apparatus in 1895 was, in fact, taken in the joint names of Auguste and Louis Lumière, but the elder brother has made it clear that in this particular case the originator of the idea was Louis. Both brothers are members of the Paris Academy of Sciences, and have received numerous honours from scientific bodies in France and elsewhere.

\section{Human Genetics and Human Ideals*}

$\mathrm{T}$ WO widely held opinions on human genetics may be summarised as follows: (1) It is essential in the interests of national hygiene that the unfit should be sterilised; (2) some races are superior to others, the members of which cannot rise to the highest levels possible to humanity.

Both theories are largely based on analogical reasoning from the breeding of domestic animals. Although the laws of heredity are the same in men as in other mammals, the analogy is suspect because our domestic animals are far more genetically homogeneous than any human groups, having been established by intense inbreeding and selection. We must, therefore, examine the evidence for these propositions in detail.

\section{Abnormalities and Sterilisation}

Human abnormalities which are genetically determined fall into five main classes :

(1) Those due to autosomal dominant genes, which determine the abnormality in all cases; for example, lobster claw, cleidocranial dysostosis. Here the abnormality is handed down only by affected

* Substance of a Sir Halley Stewart Trust Lecture delivered by Prof. J. B. S. Haldane, F. R.S., in the Memorial Hall, Farringdon :Street, London, on November $\mathbf{b}$. persons, and to about half their children, regardless of sex.

(2) Those due to autosomal genes with manifestation in some, but not all cases. For example, blue sclerotics are due to a dominant gene with 100 per cent manifestation. A fraction of the patients develop bone fragility, deafness due to otosclerosis, or both. Huntingdon's chorea, due to a dominant gene, may not develop until the age of seventy years, though the average age is thirty-five. Such abnormalities run in a family, are handed down to lass than half the progeny of affected persons, and often skip a generation.

(3) Those due to sex-linked genes. These are often manifested wholly, or almost wholly, in males and transmitted by females, for example, hæmophilia. But they may be incompletely recessive in heterozygous females, and affect a proportion of them, as with Leber's disease (atrophy of the optic nerve).

(4) Those due to autosomal recessive genes. These are not hereditary in the ordinary sense. They are very rarely handed down from ancestor to offspring, but occur in one or more children of a pair, both of whom are heteroz gous. They are very much more frequent in the offspring of parents who are related to one another, for example, of first cousins, than in the general population. They include amaurotic 